\title{
PENGARUH RASIO KEUANGAN TERHADAP HARGA SAHAM PERBANKAN SYARIAH TERDAFTAR BURSA EFEK INDONESIA
}

\author{
Chandra Satria \\ Ekonomi syariah, Sekolah Tinggi Ekonomi dan Bisnis Syariah Indo Global Mandiri \\ Email: Chandras@ stebisigm.ac.id \\ Yeken Suhiba Putri \\ Mahasiswa Ekonomi syariah, Sekolah Tinggi Ekonomi dan Bisnis Syariah Indo Global Mandiri \\ Email: yheken1106@gmail.com
}

\begin{abstract}
One of indicator of the nation economic performance is indicated by the amount of investment by business actors involved either directly or indirectly in the participation of shares or a number of investments that occur within one country. Banking financial performance is a description of the achievement of financial management targets, either from the collection of third party funds or channeled back in the form of investment products or other financing. Currently, Islamic finance is growing rapidly with many Islamic financial institutions offering financial products and services based on Islamic law. This Developmental conditions have an influence on the picture of Islamic stock investment in the capital market, althought sharia stock investment is not as big as existing conventional stocks. The purpose of this study is to determine the effect of financial ratios in Indonesian Islamic banks on the movement of the value of their share prices. The method in this research is causal associative through secondary data sources in the form of Islamic bank financial reports in the past few years. The results showed that in partial analysis there was no effect of share prices on the level of Islamic bank financial ratios, while simultaneously, there was an effect of Islamic bank financial ratios on Islamic bank share prices in the capital market.
\end{abstract}

Keywords: ROA Ration, DER Ratio, CR Ratio, Islamic bank share prices

\begin{abstract}
Abstrak
Salah satu indikator kinerja perekonomian bangsa ditunjukkan dengan besarnya investasi oleh pelaku usaha yang terlibat baik secara langsung maupun tidak langsung dalam penyertaan saham atau sejumlah investasi yang terjadi dalam satu negara. Kinerja keuangan perbankan merupakan gambaran pencapaian sasaran pengelolaan keuangan, baik dari penghimpunan dana pihak ketiga maupun yang disalurkan kembali dalam bentuk produk investasi atau pembiayaan lainnya. Saat ini, keuangan syariah sedang berkembang pesat dengan banyaknya lembaga keuangan syariah yang menawarkan produk dan jasa keuangan berdasarkan hukum Islam. Kondisi perkembangan ini berpengaruh terhadap gambaran investasi saham syariah di pasar modal, walaupun investasi saham syariah tidak sebesar saham konvensional yang ada. Tujuan
\end{abstract}


penelitian ini adalah untuk mengetahui pengaruh rasio keuangan pada bank syariah Indonesia terhadap pergerakan nilai harga sahamnya. Metode dalam penelitian ini adalah asosiatif kausal melalui sumber data sekunder berupa laporan keuangan bank syariah beberapa tahun terakhir. Hasil penelitian menunjukkan bahwa secara analisis parsial tidak terdapat pengaruh harga saham terhadap tingkat rasio keuangan bank syariah, sedangkan secara simultan terdapat pengaruh rasio keuangan bank syariah terhadap harga saham bank syariah di pasar modal.

Kata Kunci: $\quad$ Rasio ROA, Rasio DER, Rasio CR, harga saham bank syariah

\section{Dasar Pemikiran}

Perbankan syariah secara umum bertujuan untuk memajukan dan mempercepat pertumbuhan perekonomian pada masyarakat berdasarkan prinsip atau kaidah syariah. Bank Umum Syariah mengalami perkembangan yang cukup pesat sampai tahun 2019. Data Otoritas Jasa Keuangan (OJK) Republik Indonesia sampai dengan Febuari 2019 menunjukkan bahwa Bank Umum Syariah di Indonesia mengalami perkembangan yang sangat pesat ditandai dengan berdirinya 14 Bank Umum Syariah, yaitu PT Bank Mualamat Indonesia, PT Bank Syariah Mandiri, PT Bank Mega Syariah, PT Bank BRI Syariah, PT Bank Syariah Bukopin, PT Bank BNI Syariah, PT Bank Jabar Banten Syariah, PT BCA Syariah, PT Bank Victoria Syariah, PT Maybank Syariah Indonesia, PT Bank Panin Syariah, PT Bank Tabungan Pensiunan Nasional Syariah, PT Bank Danaman Indonesia, dan PT Bank Permata. Dari 14 Bank Umum Syariah tersebut, yang terdaftar dalam Bursa Efek Indonesia (BEI) berjumlah 6 bank, yaitu PT Bank Syariah Bukopin, Bank Danamon Indonesia, Bank Permata, Bank BRI Syariah, Bank Tabungan Pensiunan Syariah, dan Bank Panin Dubai Syariah. Menyatunya perekonomian nasional ke dalam tatanan ekonomi dunia, menimbulkan ketidakpastian usaha menjadi ciri dalam dinamika perekonomian global yang harus dihadapi oleh perekonomian Indonesia. Oleh karena itu, setiap perusahaan mampu menyesuaikan dengan keadaan pertumbuhan perekonomian nasional. Selain itu juga, perusahaan harus mampu mengolah sumber daya yang ada dalam perusahaan agar tetap dapat berkembang dan dapat menjalankan segala aktivitas perusahaan dengan efektif sehingga dapat menarik investor dalam menginvestasikan dananya (Sujarweni, 2018)

Salah satu indicator kinerja perekonomian suatu bangsa ditandai dengan adanya besaran investasi pelaku usaha yang terlibat baik langsung maupun dalam penyertaan 
saham. Untuk Saham syari'ah sendiri menurut otoritas jasa keuangan (OJK) Republik Indonesia adalah surat berharga bukti penyertaan modal kepada perusahaan dan dengan bukti penyertaan tersebut pemegang saham berhak untuk mendapatkan bagian hasil dari usaha perusahaan tersebut. Konsep penyertaan modal dengan hak bagian hasil usaha ini merupakan konsep yang tidak bertentangan dengan prinsip syariah. Prinsip syariah mengenal konsep ini sebagai kegiatan musyarakah atau syirkah. Menurut Fatwa Dewan Syari'ah Nasiona No:08/DSN-MUI/IV/2000 tentang Pembiayaan Musyakarah, yang dimaksud pembiayaan musyarakah adalah pembiayaan berdasarkan akad kerjasama antara dua pihak atau lebih untuk suatu usaha tertentu, di mana masing-masing pihak memberikan kontribusi dana dengan ketentuan bahwa keuntungan dan resiko akan ditanggung bersama sesuai dengan kesepakatan.(MUI, 2000) Berdasarkan Fatwa tersebut, Divisi Pengembangan Produk dan Edukasi Departemen Perbankan Syariah Otoritas Jasa Keuangan, akad musyarakah salah satu jenis kontrak yang diterapkan oleh perbankan syariah. Musyarakah diterapkan melalui mekanisme pembagian keuntungan serta kerugian (profit loss sharing) diantara para pihak (mitra/syarik) melalui metode profit maupun revenue sharing. Porsi pembiayaan dengan akad Musyarakah saat ini hanya berkontribusi sebesar 22\% dari total pembiayaan Perbankan Syariah Indonesia. Konsep profit loss sharing dalam akad Musyarakah merupakan ciri khusus sebagai pembeda antara aktivitas perbankan syariah dengan perbankan konvensional. Tanggung renteng atas keuntungan dan kerugian yang dialami antara Bank dan Nasabah menjadi kriteria khusus yang dapat menarik jumlah Nasabah lebih banyak jika Bank mampu mengelola risiko dengan baik.(OJK, 2016) Perspektif Islam mengenai saham syariah dengan prinsip musyarakah terkandung dalam Al-Quran surat Shaad ayat 24 :

Artinya:

"Dan sesungguhnya kebanyakan dari orang-orang yang berserikat itu sebagian mereka berbuat dhalim kepada sebagian yang lain, kecuali orang-orang yang beriman dan mengerjakan amal sholeh". (RI, 1997)

T.M. Hasbi Ash Shidieqy menafsirkan bahwa kebanyakan orang yang bekerjasama itu selalu ingin merugikan mitra usahanya, kecuali mereka yang beriman 
dan melakukan amalan yang sholeh karena merekalah yang tidak mau mendhalimi orang lain. Tetapi alangkah sedikitnya jumlah orang-orang yang seperti itu.(Shidieqy, 2000). Awal kemunculan Bank Syariah di Indonesia sendiri dimulai pada tahun 1991, yaitu ditandai dengan berdirinya bank syariah pertama di Indonesia yaitu PT Bank Muamalat Indonesia Tbk. Pemerintah pada tahun 2008 telah mengesahkan dasar hukum mengenai perbankan syariah melalui Undang-Undang No. 21 tahun 2008 ditujukan dengan harapan agar kedudukan Bank Syariah di tengah-tengah masyarakat semakin menguat.(Suwikna, 2016). Laba dan arus kas suatu perusahaan dapat kita lihat dari kinerja keuangan perusahaan, sehingga peningkatan performa atau kinerja keuangan perusahaan sangatlah penting untuk diperhatikan. indikator kinerja perusahaan akan tercermin pada laporan keuangan perusahaan.(Bahri, 2016) Laporan keuangan harus mencerminkan kinerja keuangan yang baik sehingga dapat menjadi daya tarik bagi investor dalam melakukan investasi pada suatu perusahaan. Laporan keuangan didesain agar beberapa pihak yang berkepentingan dan membutuhkan dapat mengindentifikasi keterkaitan antara beberapa variabel dengan variabel lainnya dalam suatu laporan keuangan. Pihak yang berkepentingan yang dimaksud salah satunya adalah investor. Salah satu pertimbangan investor untuk mengnvestasikan modalnya di pasar modal yaitu dengan melihat laporan keuangan perusahaan yang listing di pasar modal tersebut.(Husnan, 2015)

Kinerja keuangan perbankan merupakan gambaran tentang pencapaian target pengelolaan keuangan baik bersumber dari penghimpunan dana pihak ketiga maupun disalurkan kembali dalam bentuk produk investasi atau pembiayaan lainnya. Penurunan kinerja perbankan syariah dapat menurunkan kepercayaan masyarakat. Oleh karena itu, bank harus dapat menjaga kepercayaan masyarakat sehingga kinerja utama bank dalam menghimpun (mengumpulkan) dana dari masyarakat dapat tercapai sehingga lebih lanjut dapat meningkatkan pendapatan bank.. Pendapatan yang akan diterima bank melalui pembiayaan digunakan untuk membiayai aktivitas operasional bank. Dalam mengukur kinerja keuangan banka ada beberapa indicator yang bisa dijadikan acuan varibabel pengukurannya yaitu tingkat profitabilitas, Return on Asset (ROA). Current Ratio (CR), Debt to Equity Ratio (DER) 
Pengukuran Return On Asset (ROA), Curret Ratio (CR), Debt to Equity Ratio (DER) dan harga saham dapat dilihat pada tabel berikut:

Tabel 1

ROA, CR, DER dan Harga Saham

\begin{tabular}{|c|c|r|r|r|c|}
\hline \multirow{4}{*}{ EMITEN } & Tahun & $\begin{array}{c}\text { ROA } \\
(\%)\end{array}$ & \multicolumn{1}{c|}{$\begin{array}{c}\text { CR } \\
(\%)\end{array}$} & $\begin{array}{c}\text { DER } \\
(\%)\end{array}$ & $\begin{array}{c}\text { Harga Saham } \\
(\mathrm{Rp})\end{array}$ \\
\hline \multirow{4}{*}{ PNBS } & 2014 & 1,99 & 68,21 & 476,64 & 189 \\
\cline { 2 - 6 } & 2015 & 1,14 & 34,39 & 517,42 & 250 \\
\cline { 2 - 6 } & 2016 & 0,37 & 28,16 & 637,24 & 120 \\
\cline { 2 - 6 } & 2017 & $-10,77$ & 34,38 & $3.047,12$ & 65 \\
\cline { 2 - 6 } & 2018 & 0,26 & 32,83 & 425,70 & 50 \\
\hline \multirow{3}{*}{ BRIS } & 2018 & 0,43 & 349,06 & 215,83 & 525 \\
\cline { 2 - 6 } & 2019 & 0,31 & 362,99 & 233,49 & 330 \\
\hline BTPS & 2018 & 12,40 & 54,50 & 201,20 & 1.795 \\
\hline \multirow{3}{*}{ BNLI } & 2016 & -4.90 & 113,19 & 758,12 & 550 \\
\cline { 2 - 6 } & 2017 & 0,60 & 116,96 & 597,30 & 625 \\
\cline { 2 - 6 } & 2018 & 0,80 & 117,21 & 589,30 & 620 \\
\hline \multirow{3}{*}{ BDMN } & 2016 & 2,50 & 26,35 & 126,35 & 3.629 \\
\cline { 2 - 6 } & 2017 & 3,10 & 28,16 & 128,16 & 5.493 \\
\cline { 2 - 6 } & 2018 & 3,10 & 28,96 & 128,96 & 7.550 \\
\hline & 2015 & 0,75 & 93,72 & $1.491,59$ & 700 \\
\cline { 2 - 6 } & 2016 & 0,54 & 93,28 & $1.474,84$ & 640 \\
\cline { 2 - 6 } & 2017 & 0,09 & 93,65 & $1.387,38$ & 625 \\
\hline \multirow{3}{*}{ BBKP } & 2018 & 0,22 & 91,01 & $1.012,86$ & 580 \\
\hline
\end{tabular}

(Sumber Pengelolaan : IDX, 2020)

.Penelitian terdahulu mengenai pengaruh ROA, CR dan DER terhadap harga saham Perbankan Syariah telah menyimpulkan hasil yang berbeda-beda. Penelitian Aryanti (2016) dan Nur Ahmadi Bi Rahmani (2019) menyatakan bahwa ROA berpengaruh positif dan signifikan terhadap harga saham. Sedangkan Indri Ludyah 
304 | Chandra Satria, Yheken Suhiba Putri, Pengaruh Rasio KeUANGan TERHADAP haRGa ......

(2017) menyimpulkan ROA berpengaruh tidak signifikan terhadap harga saham. Studi Agung Anugrah (2017) dan Ilham Iqbal Islami (2018) menyatakan bahwa DER berpengaruh positif dan signifikan terhadap harga saham. Sedangkan penelitian Indri Ludyah (2017) dan Nyimas Artina (2017) menyatakan bahwa DER berpengaruh tidak signifikan terhadap harga saham. Penelitian Agung Anugrah (2017) menyimpulkan bahwa CR berpengaruh positif dan signifikan terhadap harga saham. Sedangkan Aryanti (2016) menyatakan bahwa CR berpengaruh tidak signifikan terhadap harga saham.

Berdasarkan latar belakang permasalahan di atas dan hasil penelitian terdahulu, yaitu rasio ROA, CR dan DR masing-masing perbankan syariah menunjukkan tingkat fluktuatif dan perubahan yang cukup dinamis, demikian juga harga saham untuk tiap tahunnya mengalami perubahan. Oleh karena itu, peneliti tertarik melakukan suatu penelitian yang berjudul: "Pengaruh ROA, CR, DER Terhadap Harga Saham Perbankan Syariah yang Terdaftar dalam Bursa Efek Indonesia". kerangka Pemikiran dalam penelitian ini adalah

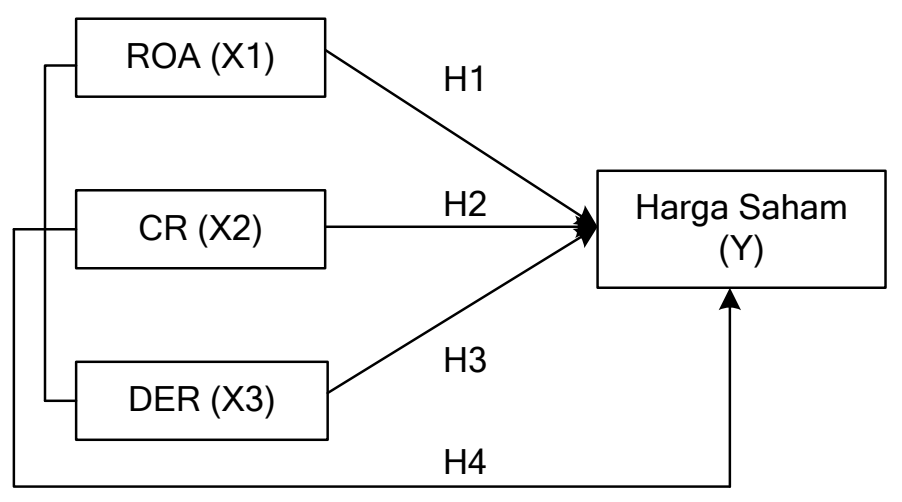

Paradigma di atas, menunjukkan adanya empat (4) variabel, yaitu variabel dependent dan variabel independent, dalam penelitian ini adalah harga saham (Y), sedangkan variabel independent meliputi ROA (X1), CR (X2), dan DER (X3). Dan perbandingan laba setelah pajak dengan total asset, $\mathrm{CR}$ adalah perbandingan aktiva lancar dengan hutang lancar, DER adalah perbandingan total hutang dengan total ekuitas.

\section{Metode Penelitian}


ISLAMIC BANKING: Jurnal Pemikiran dan Pengembangan Perbankan Syariah, Volume 6 Nomor 2 Edisi Februari 2021

Objek Penelitian adalah laporan keuangan perbankan syariah yang terdaftar di Bursa Efek Indonesia dalam beberapa periode yang sudah ditentukan. Operasional Variabel

\section{terdiri dari}

1) Variabel independen $(\mathrm{X})$ dalam penelitian ini adalah terdiri dari ROA $\left(\mathrm{X}_{1}\right), \mathrm{CR}$ $\left(\mathrm{X}_{2}\right)$, dan DER $\left(\mathrm{X}_{3}\right)$.

2) Variabel dependen dalam penelitian ini adalah harga saham (Y). Harga saham perbankan syariah yang tidak pernah dislisting maupun baru melakukan penawaran umum. Periode penelitian didasarkan pada data yang digunakan dalam analisis merupakan data historis,

Metode dalam penelitian ini adalah asosiatif kausal. Menurut Sugiyono, penelitian asosiatif kausal merupakan hubungan yang bersifat sebab akibat. Jadi disini ada variabel independen (variabel yang mempengaruhi) dan dependen (dipengaruhi).(Sugiyono, 2018)

Populasi Dalam penelitian ini yang menjadi populasi adalah perbankan syariah yang terdaftar dalam Bursa Efek Indonesia periode 2014-2019(Sugiyono, 2018). Menurut data terdapat 6 perusahaan sebagaimana terlihat pada tabel berikut.

Tabel 2 Populasi Penelitian

\begin{tabular}{|c|l|c|}
\hline No & Perbankan Syariah & Emiten \\
\hline 1 & Bank Panin Dubai Syariah & PNBS \\
\hline 2 & BRI Syariah & BRIS \\
\hline 3 & Bank Tabungan Pensiunan Syariah & BTPS \\
\hline 4 & Bank Permata & BNLI \\
\hline 5 & Bank Danamon Indonesia & BDMN \\
\hline 6 & Bank Bukopin Syariah & BBKP \\
\hline
\end{tabular}

Sampel dalam penelitian ini menggunakan teknik sampling jenus, yaitu teknik penentuan sampel bila semua populasi digunakan sebagai sampel.(Sugiyono, 2018) Hal ini sering dilakukan bila jumlah populasi relatif kecil, kurang dari 100. 
306 | Chandra Satria, Yheken Suhiba Putri, Pengaruh Rasio KeUANGan TERHADAP haRGa ......

Teknik Pengumpulan Data dalam penelitian ini adalah metode dokumentasi:(Sunyoto, 2016). Metode ini digunakan untuk memperoleh data laporan keuangan tahunan dan harga saham perbankan syariah yang listing pada Bursa Efek Indonesia (BEI) periode 2014-2019, dan untuk memperoleh data dari dokumen-dokumen tertulis dengan mempelajari berbagai tulisan dari buku, jurnal, dan internet yang berkaitan dan mendukung penelitian ini.

Teknik Analisis Data yang digunakan dalam penelitian ini adalah deskriptif kuantitatif dan statistik deskriptif. Analisis data dalam penelitian adalah uji asumsi klasik, regresi linear ganda dan uji hipotesis.

\section{Hasil Penelitian}

Rekap Hasil ROA, CR, DER dan Harga Saham

Tabel 3

Bank Bukopin Periode 2015-2019

\begin{tabular}{|c|c|c|c|c|c|}
\hline EMITEN & Tahun & $\begin{array}{c}\text { ROA } \\
(\%)\end{array}$ & $\begin{array}{c}\text { CR } \\
(\%)\end{array}$ & $\begin{array}{c}\text { DER } \\
(\%)\end{array}$ & $\begin{array}{c}\text { Harga Saham } \\
(\mathrm{Rp})\end{array}$ \\
\hline \multirow{5}{*}{ BBKP } & 2015 & 0,75 & 93,72 & $1.491,59$ & 700 \\
\cline { 2 - 6 } & 2016 & 0,54 & 93,28 & $1.474,84$ & 640 \\
\cline { 2 - 6 } & 2017 & 0,09 & 93,65 & $1.387,38$ & 625 \\
\cline { 2 - 6 } & 2018 & 0,22 & 91,01 & $1.012,86$ & 580 \\
\cline { 2 - 6 } & 2019 & 0,13 & 91,12 & $1.025,87$ & 334 \\
\hline
\end{tabular}

Tabel 4

Bank Danamon Periode 2016-2019

\begin{tabular}{|c|c|c|c|c|c|}
\hline EMITEN & Tahun & $\begin{array}{c}\text { ROA } \\
(\%)\end{array}$ & $\begin{array}{c}\text { CR } \\
(\%)\end{array}$ & $\begin{array}{c}\text { DER } \\
(\%)\end{array}$ & $\begin{array}{c}\text { Harga Saham } \\
(\mathrm{Rp})\end{array}$ \\
\hline \multirow{3}{*}{ BDMN } & 2016 & 2,50 & 26,35 & 126,35 & 3.629 \\
\cline { 2 - 6 } & 2017 & 3,10 & 28,16 & 128,16 & 5.493 \\
\cline { 2 - 6 } & 2018 & 3,10 & 28,96 & 128,96 & 7.550 \\
\cline { 2 - 6 } & 2019 & 3,00 & 30,66 & 130,66 & 3.950 \\
\hline
\end{tabular}




\section{Tabel 5}

Bank Permata Periode 2016-2019

\begin{tabular}{|c|c|c|c|c|c|}
\hline EMITEN & Tahun & $\begin{array}{c}\text { ROA } \\
(\%)\end{array}$ & $\begin{array}{c}\text { CR } \\
(\%)\end{array}$ & $\begin{array}{c}\text { DER } \\
(\%)\end{array}$ & $\begin{array}{c}\text { Harga Saham } \\
(\mathrm{Rp})\end{array}$ \\
\hline \multirow{3}{*}{ BNLI } & 2016 & -4.90 & 113,19 & 758,12 & 550 \\
\cline { 2 - 6 } & 2017 & 0,60 & 116,96 & 597,30 & 625 \\
\cline { 2 - 6 } & 2018 & 0,80 & 117,21 & 589,30 & 620 \\
\cline { 2 - 6 } & 2019 & 1,30 & 117,49 & 579,00 & 1.265 \\
\hline
\end{tabular}

Tabel 6

Bank BRI Syariah Periode 2018-2019

\begin{tabular}{|c|c|c|c|c|c|}
\hline EMITEN & Tahun & $\begin{array}{c}\text { ROA } \\
(\%)\end{array}$ & $\begin{array}{c}\text { CR } \\
(\%)\end{array}$ & $\begin{array}{c}\text { DER } \\
(\%)\end{array}$ & $\begin{array}{c}\text { Harga Saham } \\
(\mathrm{Rp})\end{array}$ \\
\hline \multirow{2}{*}{ BRIS } & 2018 & 0,43 & 349,06 & 215,83 & 525 \\
\cline { 2 - 6 } & 2019 & 0,31 & 362,99 & 233,49 & 330 \\
\hline
\end{tabular}

Tabel 7

Bank Tabungan Pensiunan Syariah Periode 2018-2019

\begin{tabular}{|c|c|c|c|c|c|}
\hline EMITEN & Tahun & $\begin{array}{c}\text { ROA } \\
(\%)\end{array}$ & $\begin{array}{c}\text { CR } \\
(\%)\end{array}$ & $\begin{array}{c}\text { DER } \\
(\%)\end{array}$ & $\begin{array}{c}\text { Harga Saham } \\
(\mathrm{Rp})\end{array}$ \\
\hline \multirow{2}{*}{ BRIS } & 2018 & 12,40 & 54,50 & 201,20 & 1.795 \\
\cline { 2 - 6 } & 2019 & 13,60 & 54,80 & 185,20 & 4.250 \\
\hline
\end{tabular}

Tabel 8

Bank Panin Dubai Syariah Periode 2015-2018

\begin{tabular}{|c|c|c|c|c|c|}
\hline EMITEN & Tahun & $\begin{array}{c}\text { ROA } \\
(\%)\end{array}$ & $\begin{array}{c}\text { CR } \\
(\%)\end{array}$ & $\begin{array}{c}\text { DER } \\
(\%)\end{array}$ & $\begin{array}{c}\text { Harga Saham } \\
(\mathrm{Rp})\end{array}$ \\
\hline \multirow{2}{*}{ PNBS } & 2014 & 1,99 & 68,21 & 476,64 & 189 \\
\cline { 2 - 6 } & 2015 & 1,14 & 34,39 & 517,42 & 250 \\
\hline
\end{tabular}


308 Chandra Satria, Yheken Suhiba Putri, PENGARUH RAsio KeUANGAN TERHADAP HARGA ......

\begin{tabular}{|r|r|r|r|r|c|}
\hline & 2016 & 0,37 & 28,16 & 637,24 & 120 \\
\cline { 2 - 6 } & 2017 & $-10,77$ & 34,38 & $3.047,12$ & 65 \\
\cline { 2 - 6 } & 2018 & 0,26 & 32,83 & 425,70 & 50 \\
\hline
\end{tabular}

Analisis Data dalam penelitian ini meliputi :

Tabel 9

Hasil Pengujian Multikolinearitas

Coefficients $^{\mathrm{a}}$

\begin{tabular}{|l|l|c|c|}
\hline \multicolumn{2}{|l|}{ Model } & \multicolumn{2}{c|}{ Collinearity Statistics } \\
\cline { 3 - 4 } \multicolumn{2}{|l|}{} & Tolerance & VIF \\
\hline 1 & $\mathrm{X} 1$ & .478 & 2.091 \\
& $\mathrm{X} 2$ & .814 & 1.228 \\
& $\mathrm{X} 3$ & .458 & 2.183 \\
\hline
\end{tabular}

a. Dependent Variable: Y

Berdasarkan output di atas diketahui bahwa melihat nilai Tolerance variabel ROA $\left(\mathrm{X}_{1}\right), \mathrm{CR}\left(\mathrm{X}_{2}\right)$, dan DER $\left(\mathrm{X}_{3}\right)$ lebih besar dari > 0,10, bahwa ini menandakan tidak terjadi Multikolinieritas sedangkan nilai VIF ROA (X1), CR (X2), DER (X3), lebih kecil dari < 10,00, sehingga dapat disimpulkan data Perbankan Syariah tidak terjadi multikolonieritas.

1) Uji Heterokedastistas

\section{Gambar 2}




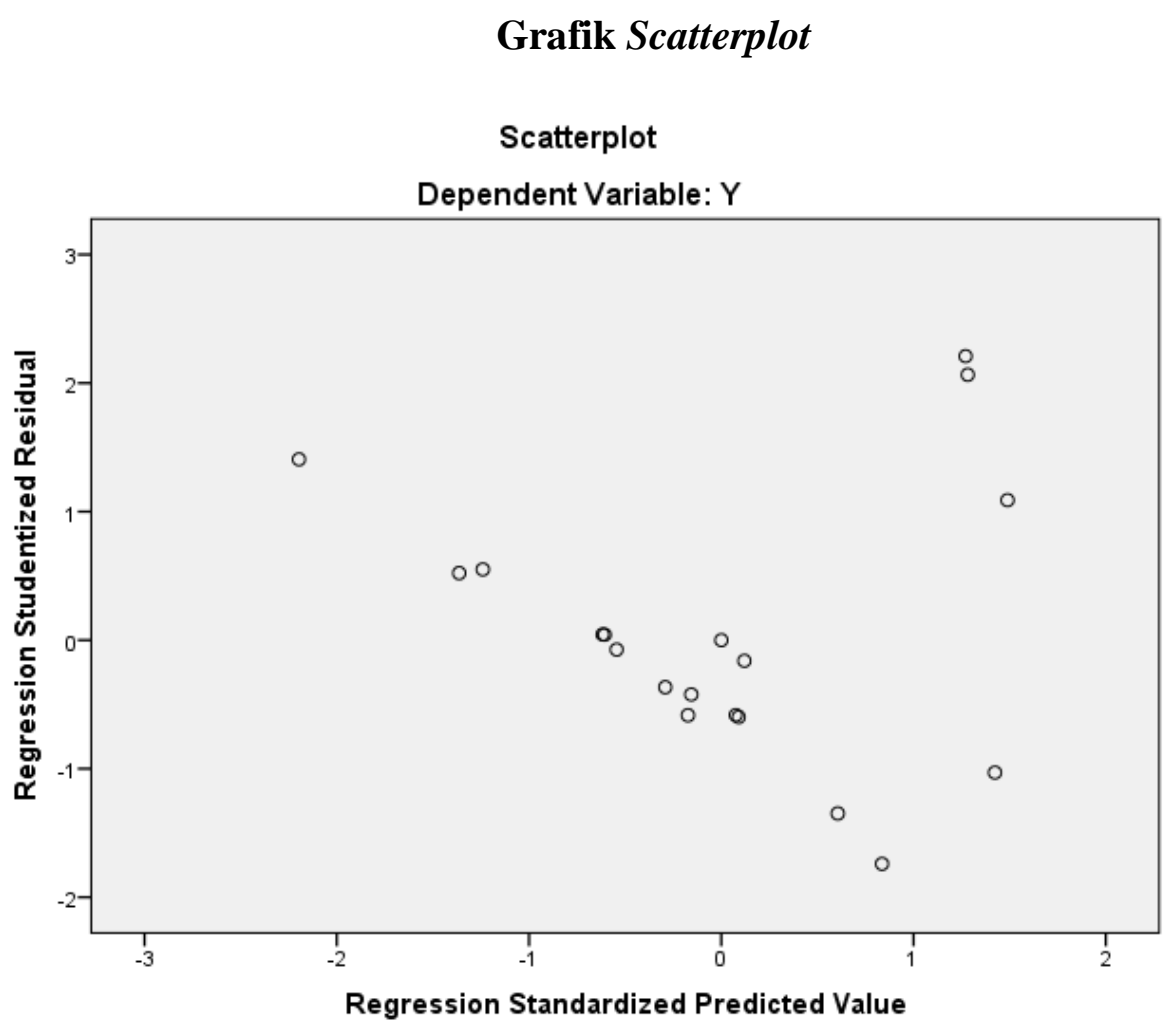

Berdasarkan gambar grafik scatterplot di atas, diketahui bahwa titiktitik data penyebar di atas dan di bawah atau di sekitar angka 0, titik-titik tidak mengumpul hanya di atas atau di bawah saja, penyebaran titik-titik data tidak membentuk pola bergelombang melebar kemudian menyempit dan melebar kembali, serta penyebaran titik-titik data tidak berpola. Dengan demikian, dapat disimpulkan bahwa tidak terjadi masalah heterokedasitistas, sehingga model regresi yang baik dan ideal dapat terpenuhi.

2) Uji Normalitas

Tabel 10

Hasil Uji Normalitas

One-Sample Kolmogorov-Smirnov Test

\begin{tabular}{|ll|r|}
\hline & $\begin{array}{c}\text { Unstandardized } \\
\text { Residual }\end{array}$ \\
\hline Normal Parameters & a,b & Mean \\
& Std. Deviation & 19 \\
Most Extreme Differences & Absolute & .0000000 \\
& & .166
\end{tabular}


310 Chandra Satria, Yheken Suhiba Putri, PeNGARUH RASIO KEUANGAN TERHADAP HARGA ......

\begin{tabular}{|ll|r|} 
& Positive & .166 \\
& Negative & -.105 \\
Test Statistic & & .166 \\
Asymp. Sig. (2-tailed) & & $.176^{c}$ \\
\hline
\end{tabular}

a. Test distribution is Normal.

Berdasarkan tabel di atas, diketahui bahwa nilai signifikansi sebesar 0,176 bearti lebih besar dari > 0,05, sehingga dapat disimpulkan bahwa data yang diuji berdistribusi normal atau yang berarti menerima $\mathrm{H} 0$.

3) Uji Autokorelasi 
Tabel 11

Hasil Pengujian Autokorelasi dengan Durbin Watson

\begin{tabular}{|l|r|}
\multicolumn{2}{|c|}{ Model Summary ${ }^{\mathrm{b}}$} \\
\begin{tabular}{|l|r|}
\hline Model & \multicolumn{1}{|c|}{ Durbin-Watson } \\
\hline 1 & \\
\hline
\end{tabular}
\end{tabular}

a. Predictors: (Constant), X3, X2, X1

b. Dependent Variable: $Y$

\begin{tabular}{|c|c|c|c|c|c|c|}
\hline $\mathrm{K}$ & $\mathrm{N}$ & $\mathrm{D}$ & $\mathrm{DL}$ & $\mathrm{DU}$ & $4-\mathrm{DL}$ & 4-DU \\
\hline 3 & 19 & 1.887 & 0.966 & 1.685 & 3.034 & 2.315 \\
\hline
\end{tabular}

Hasil $=\mathrm{DU}<\mathrm{D}<4-\mathrm{DU}$

$$
=1.685<1.887<2.315
$$

Berdasarkan tabel di atas, diketahui nilai Durbin-Watson (DW) 1,887, selanjutnya nilai tersebut dibandingkan dengan nilai tabel signifikansi $5 \%$, jumlah sampel $\mathrm{N}=19$ dan jumlah variabel independen $3(\mathrm{~K}=3)=3.19$ sehingga diperoleh nilai du 1,685, sedangkan nilai $4-\mathrm{du}(4-1,685=2,315)$. Dengan demikian dapat dinyatakan bahwa 1,685 $<1,887<2,315$, sehingga disimpulkan bahwa tidak terdapat autokorelasi.

b. Regresi Berganda

\section{Tabel 12}

\section{Hasil Regresi Berganda}

\section{Coefficients $^{\mathrm{a}}$}

\begin{tabular}{|c|c|c|c|c|c|c|}
\hline \multirow{2}{*}{\multicolumn{2}{|c|}{ Model }} & \multicolumn{2}{|c|}{ Unstandardized Coefficients } & \multirow{2}{*}{$\begin{array}{c}\begin{array}{c}\text { Standardized } \\
\text { Coefficients }\end{array} \\
\text { Beta }\end{array}$} & \multirow[b]{2}{*}{$\mathrm{t}$} & \multirow[b]{2}{*}{ Sig. } \\
\hline & & $\mathrm{B}$ & Std. Error & & & \\
\hline \multirow[t]{4}{*}{1} & (Constant) & 3050.487 & 978.076 & & 3.119 & .007 \\
\hline & $\mathrm{X} 1$ & 49.906 & 96.148 & .146 & .519 & .611 \\
\hline & $\mathrm{X} 2$ & -8.329 & 4.054 & -.443 & -2.054 & .058 \\
\hline & X3 & -1.117 & .708 & -.454 & -1.578 & .135 \\
\hline
\end{tabular}

a. Dependent Variable: Y 
Berdasarkan Tabel 13 di atas, diperoleh persamaan regresi berganda sebagai berikut:

$$
\begin{aligned}
& \widehat{Y}=a+b_{1} x_{1}+b_{2} x_{2}+b_{3} x_{3}+e \\
& \widehat{Y}=3050,487+49,906 x_{1}-8,329 x_{2}-1,117 x_{3}+978,076
\end{aligned}
$$

Persamaan regresi di atas dapat dijelaskan sebagai berikut:

1) Konstanta (a) $=3050,487$

Nilai konstanta (a) sebesar 3050,487 artinya jika variabel ROA $\left(\mathrm{X}_{1}\right)$, CR $\left(\mathrm{X}_{2}\right)$, dan DER $\left(\mathrm{X}_{3}\right)$ adalah 0 , maka harga saham $(\mathrm{Y})$ nilainya adalah 3050,487 .

2) Koefisien $\operatorname{ROA}\left(\mathrm{X}_{1}\right)=49,906$

Nilai koefisien ROA $\left(\mathrm{X}_{1}\right)$ sebesar 49,906, yang menyatakan bahwa setiap terjadi kenaikan $1 \%$ untuk variabel ROA $\left(\mathrm{X}_{1}\right)$ akan diikuti peningkatan variabel harga saham (Y) sebesar 49,906 dengan asumsi variabel lain dianggap konstanta.

3) Koefisien CR $\left(X_{2}\right)=-8,329$

Nilai koefisien CR $\left(\mathrm{X}_{2}\right)$ sebesar -8,329, yang menyatakan bahwa setiap terjadi kenaikan $1 \%$ untuk variabel $\mathrm{CR}\left(\mathrm{X}_{2}\right)$ akan diikuti penurunan variabel harga saham (Y) sebesar -8,329 dengan asumsi variabel lain dianggap konstanta.

4) Koefisien $\operatorname{DER}\left(\mathrm{X}_{3}\right)=-1,117$

Nilai koefisien DER $\left(\mathrm{X}_{3}\right)$ sebesar -1,117, yang menyatakan bahwa setiap terjadi kenaikkan $1 \%$ untuk variabel DER akan diikuti penurunan variabel harga saham (Y) sebesar $-1,117$ dengan asumsi variabel lain dianggap konstanta.

c. Koefisien Determinan

\section{Tabel 13}

Uji Determinan (Uji $\mathbf{R}^{2}$ )

Model Summary ${ }^{b}$

\begin{tabular}{|c|c|c|c|c|}
\hline Model & $\mathrm{R}$ & R Square & $\begin{array}{c}\text { Adjusted R } \\
\text { Square }\end{array}$ & $\begin{array}{c}\text { Std. Error of the } \\
\text { Estimate }\end{array}$ \\
\hline
\end{tabular}




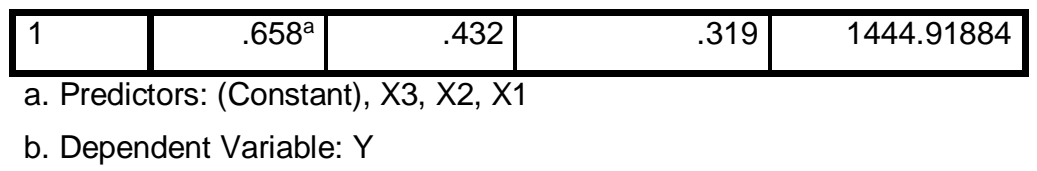

Tabel 14 di atas, diperoleh $R$ Square sebesar 0,432 atau 43,2\%. Hal ini berarti variabel harga saham mampu dijelaskan oleh variabel ROA, CR dan DER sebesar 43,2 \%. Sedangkan sisanya sebesar 56,8\% dipengaruhi oleh faktor lain yang tidak dibahas dalam penelitian ini. Standard Error Of Estimate (SEE) menunjukkan nilai sebesar 1444,91884 yang berarti makin kecil nilai SEE akan membuat model regresi semakin tepat dalam memprediksi variabel dependen.

d. Pengujian Hipotesis

1) Uji Parsial (Uji-t)

a) Pengaruh ROA terhadap Harga Saham

Tabel 13 pada kolom output di atas diperoleh nilai thitung sebesar 0,519 dengan tingkat signifikasi 0,611 yang lebih besar dari > taraf signifikansi 0,05. Dengan demikian dapat dinyatakan bahwa ROA tidak berpengaruh signifikan terhadap harga saham Perbankan Syariah yang terdaftar dalam Bursa Efek Indonesia.

b) Pengaruh CR terhadap Harga Saham

Kolom output pada Tabel 13 di atas diperoleh diperoleh nilai

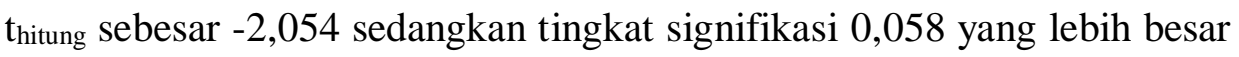
dari > taraf signifikansi 0,05. Dengan demikian dapat dinyatakan bahwa CR tidak berpengaruh signifikan terhadap harga saham Perbankan Syariah yang terdaftar dalam Bursa Efek Indonesia.

c) Pengaruh DER terhadap Harga Saham

Kolom output pada Tabel 13 di atas diperoleh diperoleh nilai $\mathrm{t}_{\text {hitung }}$ sebesar -1,578 sedangkan tingkat signifikasi 0,135 yang lebih besar dari > taraf signifikansi 0,05. Dengan demikian dapat dinyatakan bahwa DER tidak berpengaruh signifikan terhadap harga saham Perbankan Syariah yang terdaftar dalam Bursa Efek Indonesia.

2) Uji Signifikasi Simultan (Uji F) 
Tabel 14

Uji-F (Uji Simultan)

ANOVA $^{\mathrm{a}}$

\begin{tabular}{|ll|c|r|r|r|r|}
\hline \multicolumn{2}{|l|}{ Model } & $\begin{array}{c}\text { Sum of } \\
\text { Squares }\end{array}$ & df & Mean Square & F & Sig. \\
\hline 1 & Regression & 23864192.171 & 3 & 7954730.724 & 3.810 & $.033^{\text {b }}$ \\
& Residual & 31316856.774 & 15 & 2087790.452 & & \\
& Total & 55181048.944 & 18 & & & \\
\hline
\end{tabular}

b. Predictors: (Constant), X3, X2, X1

Tabel 15 dari uji ANOVA atau $F_{\text {tes }}$, didapat $F_{\text {hitung sebesar 3,810 dengan tingkat }}$ signifikan 0,033. Karena probabilitas lebih kecil dari $<0,05$ maka dapat dikatakan bahwa secara bersama-sama atau simultan variabel independen ROA, CR dan DER berpengaruh secara signifikan terhadap harga saham Perbankan Syariah yang terdaftar dalam Bursa Efek Indonesia.

\section{Pembahasan}

a. Pengaruh ROA tehadap Harga Saham Perbankan Syariah

Hasil analisis data secara parsial menyatakan bahwa variabel ROA diperoleh nilai nilai $t_{\text {hitung }}$ sebesar 0,501 dengan tingkat signifikasi 0,624 yang lebih besar dari taraf signifikansi 0,05. Dengan demikian dapat dinyatakan bahwa ROA tidak berpengaruh signifikan terhadap harga saham Perbankan Syariah yang terdaftar dalam Bursa Efek Indonesia. Return on Asset (ROA) merupakan rasio yang menggambarkan kemampuan perusahaan dalam mengelola dana yang diinvestasikan dalam keseluruhan aktiva yang menghasilkan pendapatan. Hal ini selaras dengan pendapat Sujarweni menyatakan bahwa ROA adalah "rasio profitabilitas yang digunakan untuk mengukur efektivitas perusahaan di dalam menghasilkan keuntungan dengan memanfaatkan aktiva yang dimilikinya".(Sujarweni, 2018) Semakin besar ROA menunjukkan kinerja perusahaan yang semakin baik, karena tingkat kembalian investasi semakin besar. Namun, dalam penelitian ini menunjukkan bahwa nilai ROA yang rendah menyebabkan tingkat kembalian investasi yang semakin kecil. Hasil penelitian ini selaras dengan studi Aryanti (2016), dan Indri Ludyah (2017) menyimpulkan bahwa ROA tidak berpengaruh 
signifikan terhadap harga saham Perbankan Syariah. Hal ini dikarenakan investor tidak hanya memperhatikan kemampuan dari internal perusahaan dalam menghasilkan keuntungan tetapi memperhatikan risiko eksternal serta kondisi pasar. Risiko eksternal atau di luar kendali perusahaan dapat berupa inflasi, kenaikan tarif, perubahan kebijakan ekonomi serta politik. Permintaan dan penawaran di pasar modal juga berpengaruh dalam keputusan investasi yang dapat mengakibatkan fluktuasi harga saham.

b. Pengaruh CR terhadap Harga Saham Perbankan Syariah

Hasil perhitungan secara parsial dinyatakan bahwa variabel CR diperoleh nilai $\mathrm{t}_{\text {hitung }}$ sebesar -1,985 sedangkan tingkat signifikasi 0,067 yang lebih besar dari taraf signifikansi 0,05. Dengan demikian dapat dinyatakan bahwa CR tidak berpengaruh signifikan terhadap harga saham Perbankan Syariah yang terdaftar dalam Bursa Efek Indonesia. Menurut Fahmi, current ratio adalah kemampuan suatu perusahaan memenuhi kewajiban jangka pendeknya secara tepat waktu”.(Fahmi, 2015) Sedangkan menurut Kasmir, rasio lancar atau (current ratio) merupakan "rasio untuk mengukur kemampuan perusahaan dalam membayar kewajiban jangka pendek atau utang yang segerah jatuh tempo pada saat ditagih secara keseluruhan".(Kasmir, 2017) Dengan kata lain, seberapa banyak aktiva lancar yang tersedia untuk menutupi kewajiban jangka pendek yang segera jatuh tempo. Namun, berdasarkan hasil penelitian menunjukkan bahwa Perbankan Syariah tidak mampu melaksanakan kewajiban jangka pendeknya sehingga berpengaruh terhadap harga saham. Hasil penelitian ini selaras dengan studi Aryanti (2016), dan Agung Anugrah (2017) menyatakan CR tidak berpengaruh signifikan terhadap harga saham Perbankan Syariah. Tidak berpengaruh CR terhadap harga saham Perbankan Syariah dikarenakan ketidakmampuan perusahaan menutupi kewajiban jangka pendek atau besarnya utang lancari dibandingkan aktiva lancar.

c. Pengaruh DER terhadap Harga Saham Perusahaan

Berdasarkan hasil perhitungan secara parsial dinyatakan bahwa variabel DER $\left(\mathrm{X}_{3}\right)$ diperoleh nilai thitung sebesar -1,525 sedangkan tingkat signifikasi 0,150 yang lebih besar dari taraf signifikansi 0,05. Dengan demikian dapat dinyatakan bahwa DER tidak berpengaruh signifikan terhadap harga saham Perbankan Syariah yang terdaftar dalam 


\section{Chandra Satria, Yheken Suhiba Putri, PENGARUH RAsio KeUANGAN TERHADAP HARGA ......}

Bursa Efek Indonesia periode 2015-2018. Rianto menyatakan bahwa, DER merupakan "rasio solvabilitas yang digunakan untuk mengetahui berapa bagian dari setiap modal sendiri yang dijadikan jaminan untuk keseluruhan hutang (modal asing) perusahaan atau untuk menilai banyaknya hutang yang digunakan perusahaan”.(Rianto, 2013) Semakin besar hutang, semakin besar risiko yang ditanggung perusahaan. Oleh sebab itu, perusahaan yang tetap mengambil hutang sangat tergantung pada biaya relatif. Biaya hutang lebih kecil daripada dana ekuitas. Dengan menambahkan hutang ke dalam neracanya, perusahaan secara umum dapat meningkatkan profitabilitasnya, yang kemudian menaikkan harga sahamnya, sehingga meningkatkan kesejahteraan para pemegang saham dan membangun potensi pertumbuhan yang lebih besar. Sebaliknya biaya hutang lebih besar daripada dana ekuitas. Dengan menambahkan hutang ke dalam neracanya, justru akan menurunkan profitabilitas perusahaan. Selama ekonomi sulit atau suku bunga tinggi, perusahaan dengan Debt to Equity Ratio (DER) yang tinggi dapat mengalami masalah keuangan, namun sebaliknya selama ekonomi baik atau suku bunga rendah akan meningkatkan keuntungan, yaitu dengan membiayai pertumbuhan dengan harga yang rendah. Tidak berpengaruhnya DER terhadap harga saham mengidentifikasikan bahwa semakin tinggi tingkat DER maka harga saham akan turun. DER mempunyai dampak buruk bagi perusahaan yang lebih banyak menggunakan hutang dalam kegiatan operasionalnya. Semakin tinggi hutang perusahaan akan mengurangi return yang diperoleh. Perusahan yang laveragenya tinggi akan mendapatkan deviden yang kcil begitu sebaliknya perusahaan yang laveragenya rendah, karena mereka memiliki kewajiban untuk menggunakan pendapatan mereka untuk membeyar tagihan hutang. Kondisi seperti ini tidak disukai oleh investor sehingga harga saham menjadi menurun. Penelitian ini juga selaras dengan hasil studi Nyimas Artina (2017), Indri Ludyah (2017), dan Agung Anugrah (2017) menemukan bahwa DER tidak berpengaruh terhadap harga saham Perbankan Syariah.

d. Pengaruh ROA, CR dan DER terhadap Harga Saham Perbankan Syariah

Hasil perhitungan secara simultan diperoleh $F_{\text {hitung }}$ sebesar 3,810 dengan tingkat signifikan $0,33^{\mathrm{b}}$. Karena probabilitas $<0,05$ maka dapat dikatakan bahwa secara bersama-sama atau simultan variabel independen (ROA, CR dan DER) berpengaruh 
secara signifikan terhadap harga saham Perbankan Syariah yang terdaftar dalam Bursa Efek Indonesia. Penelitian ini ditinjau secara simultan menunjukkan bahwa ROA, CR dan DER memberikan pengaruh positif yang signifikan terhadap harga saham. Harga saham adalah "nilai suatu saham yang mencerminkan kekayaan perusahaan untuk mengeluarkan saham, di mana perubahan atau fluktuasinya sangat ditentukan penawaran dan permintaan yang terjadi di pasar bursa".(Husnan, 2015). Nilai pasar dari sekuritas merupakan harga pasar dari sekuritas itu sendiri. Jika sekuritas yang diperdagangkan secara aktif, nilai pasar merupakan terakhir yang dilaporkan pada saat sekuritas terjual. Harga pasar bertindak sebagai barometer dari kinerja bisnis. Harga pasar menunjukkan seberapa baik manajemen menjalankan tugasnya atas nama pemegang para pemegang saham. Pemegang saham yang tidak puas dengan kinerja perusahaan dapat menjual saham yang mereka miliki dan menginvestasikan uangnya di perusahaan lain. Tindakan-tindakan tersebut jika dilakukan oleh para pemegang saham akan mengakibatkan turunnya harga saham dipasar, karena pada dasarnya tinggi rendahnya harga saham dipengaruhi oleh ROA, CR dan DER.

\section{Simpulan}

Berdasarkan hasil pembahasan penelitian, maka dapat disimpulkan sebagai berikut: ROA secara parsial tidak berpengaruh signifikan terhadap harga saham Perbankan Syariah yang terdaftar dalam Bursa Efek Indonesia. CR secara parsial tidak berpengaruh signifikan terhadap harga saham Perbankan Syariah yang terdaftar dalam Bursa Efek Indonesia. DER secara parsial tidak berpengaruh signifikan terhadap harga saham Perbankan Syariah yang terdaftar dalam Bursa Efek Indonesia. ROA, CR dan DR secara simultan berpengaruh signifikan terhadap harga saham Perbankan Syariah yang terdaftar dalam Bursa Efek Indonesia. 


\section{DAFTAR PUSTAKA}

A. Sanusi, Metode Penelitian Bisnis. Jakarta: Salemba Empat, 2011.

A. Anugrah, "Analisis Pengaruh Return On Equity, Debt To Equity Ratio, Current Ratio, dan Price to Book Value terhadap Return Saham Syariah (Studi Kasus pada Perusahaan yang Terdaftar dalam Jakarta Islamic Index Periode 20112015)," Diponegoro J. Manag., vol. 6, no. 1, pp. 1-12, 2017.

A. Sartono, Manajemen Keuangan Teori dan Aplikasi. Yogyakarta: BPFE, 2011.

Aryanti, "Pengaruh Roa, Roe, Npm Dan Cr Terhadap Return Saham Pada Perusahaan Yang Terdaftar Di Jakarta Islamic Index (Jii)," I-Finance, vol. 2, no. 2, pp. 5471, 2016.

B. Rianto, Manajemen Risiko Perbankan Syariah di Indonesia. Jakarta: Salemba Empat, 2013.

D. Suwikna, Analisis Laporan Keuangan Perbankan Syariah. Yogyakarta: Pustaka Pelajar, 2016.

D. Sunyoto, Metodologi Penelitian Akuntansi. Bandung: Refika Aditama, 2016.

D. A. RI, Al-Quran dan Terjemahnya. Solo: CV Pustaka Mantiq, 1997.

F. Apriliani, "KEUANGAN PENGARUH RETURN ON ASSET DAN RETURN ON EQUITY TERHADAP RETURN SAHAM EMITEN LQ45,” pp. 199-208.

Hery, Analisis Laporan Keuangan. Yogyakarta: Center For Academic Publishing Service, 2015.

I. Ghozali, Aplikasi Analisis Multivariate Dengan Program IBM SPSS 21 Update Pls Regres. Semarang: Semarang : Badan Penerbit Universitas Diponegoro, 2013.

I. Fahmi, Manajemen Kinerja Teori dan Aplikasi. Bandung: Alfabeta, 2015.

I. I. Islami, "Analisis Pengaruh Return On Equity, Debt to Equity Ratio, Earning Per Share, Inflasi dan BI Rate Terhadap Volatilitas Saham Jakarta Islamic Index pada Perusahaan Sektor Properti dan Real Estate Periode 2013-2017," J. Keuang., vol. 1, no. 1, pp. 1-20, 2017.

I. Ludyah, "Pengaruh Return On Asset (ROA), Return On Equity (ROE), Debt to Equity Ratio (DER) dan Earning Per Share (EPS) Terhadap Harga Saham (Studi Empiris pada Perusahaan LQ45 yang Terdaftar di BEI Periode 2012-2016)," $e$ Jurnal Ris. Manaj., vol. 1, no. 1, pp. 82-94, 2016.

J. Hartono, Teori Portofolio dan Analisis Investasi. Yogyakarta: BPFE, 2017.

Kasmir, Analisis Laporan Keuangan. Jakarta: Rajawali Press, 2017.

L. M. Samryn, Akuntansi Manajemen Informasi Biaya untuk Mengendalikan Aktivitas Operasi \& Investasi. Jakarta: Kencana Prenada Media Group, 2012. 
MUI, Fatwa Dewan Syari'ah Nasional No: 08/DSN-MUI/IV/2000 tentang Pembiayaan Musyarakah. Jakarta, 2000.

N. A. B. Rahmani, "Pengaruh Return On Asset (ROA), Return On Equity (ROE), Net Profit Margin (NPM), dan Gross Profit Margin (GPM) Terhadap Harga Saham Perbankan Syariah Periode Tahun 2014-2018," KITABAH, vol. 3, no. 2, pp. 279288, 2019, doi: 10.1542/peds.2006-2099.

N. Artina, "Peran Mediasi Price Earning Ratio Atas Pengaruh Debt to Equity Ratio dan Return On Equity Terhadap Harga Saham pada Perusahaan Jakarta Islamic Index," J. Keuang. dan Bisnis, vol. 1, no. 1, pp. 1-16, 2017.

N. Supriantikasari and E. S. Utami, "PENGARUH RETURN ON ASSETS, DEBT TO EQUITY RATIO , CURRENT RATIO, EARNING PER SHARE DAN NILAI TUKAR TERHADAP RETURN SAHAM ( Studi Kasus Pada Perusahaan Go Public Sektor Barang Konsumsi Yang Listing Di Bursa Efek Indonesia Periode 2015-2017 ) THE EFFECT OF RETURN ON ASSETS , DEBT TO EQUITY RATIO , CURRENT RATIO, EARNING PER SHARE, AND EXCHANGE RATE ON STOCK RETURN ( Case Study of Go Public Companies in the Consumer Goods Sector Listed on the Indonesia Stock Exchange in the 20152017 Period )," vol. 5, no. 1, pp. 49-66, 2019.

R. Nafiah, “Analisis Pengaruh Rasio Keuangan Dan Variabel Makro Ekonomi Terhadap Harga Saham ( Studi Kasus Pada Perusahaan Perbankan Yang Masuk Dalam Indeks LQ45 )," vol. 4, no. 2, pp. 125-140, 2019.

Riduwan, Dasar-dasar Statistika. Bandung: Alfabeta, 2012.

R. Rahman, "ANALISIS HARGA SAHAM MELALUI PENINGKATAN KINERJA KEUANGAN: STUDI PADA PERUSAHAAN YANG TERDAFTAR DI JAKARTA ISLAMIC INDEX," no. Idx.

R. Purnomo, Pasar Uang \& Pasar Valas. Jakarta: Gramedia Pustaka Utama, 2012.

OJK, Buku Standar Produk Musyakarah dan Musyarakah Mutanaqishah. Jakarta, 2016.

Sugiyono, Metode Penelitian Kombinasi (Mixed Methods). Bandung: Alfabeta, 2018.

S. S. Harahap, Analisis Kritis atas Laporan Keuangan. Depok: Rajawali Press, 2018.

S. Bahri, Pengantar Akuntansi Berdasarkan SAK Etap dan IFRS. Yogyakarta: Andi, 2016.

S. Husnan, Dasar-dasar Teori Portofolio \& Analisis Sekuritas. Yogyakarta: UPP STIM YKPN, 2015.

Sunariyah, Pengantar Pengetahuan Pasar Modal, 6th ed. Yogyakarta: UPP STIM YKPN, 2013. 
320 Chandra Satria, Yheken Suhiba Putri, PenGaRUH RAsIO KEUANGAN TERHADAP HARGA ......

T. D. \& Fakhruddin, Pasar Modal di Indonesia. Jakarta: Salemba Empat, 2012.

T. M. H. A. Shidieqy, Koleksi Hadits-hadits Hukum. Semarang: PT Petrajaya Mitrajaya, 2000.

V. W. Sujarweni, Kupas Tuntas Penelitian Akuntansi dengan SPSS. Yogyakarta: Pustaka Baru Press, 2016.

V. W. Sujarweni, Manajemen Keuangan Teori, Aplikasi dan Hasil Penelitian. Yogyakarta: Pustaka Baru Press, 2018. 